\title{
KAJIAN AREA BANGUNAN BREAKWATER TERHADAP TEMPAT LINDUNG SPESIES IKAN DI PANTAI MATRAS KABUPATEN BANGKA
}

\author{
Study of Breakwater Building on Fish Species Protected Areas on the Matras Beach of Bangka \\ Regency
}

\author{
Ripani Gautama ${ }^{1 *}$, Okto Supratman ${ }^{2}$, dan Suci Puspita Sari ${ }^{3}$ \\ ${ }^{1,2}$ Jurusan Manajemen Sumberdaya Perairan, Fakultas Pertanian Perikanan dan Biologi, Universitas Bangka Belitung, \\ Balunijuk \\ ${ }^{3}$ Jurusan Ilmu Kelautan, Fakultas Pertanian Perikanan dan Biologi, Universitas Bangka Belitung, Balunijuk
}

Email korespondensi: rifanigautama046@gmail.com

Diterima Desember; disetujui Januari tersedia secara online April

\begin{abstract}
Alleged links Breakwater Beach area of the building as a shelter Matras fish are lots of cracks and cavities of a pile of stones that are still submerged in seawater can be overgrown with algae and the coral recruitment and attended algae fish species and fish-eating predators. This study aims to assess the area of the building Breakwater of the area protected fish species, determine the species composition, abundance of fish by category type and feeding habits of fish and fish community structure which was implemented in April 2019 in the area of the building Breakwater and NonBreakwater in Matras Beach Bangka. The method uses a combination of visual census and gill nets to take fish of data. The results of the study recorded the number of individual fish in the area as many as 3741 individual Breakwater building consists of 22 species from 14 families and Non-Breakwater much as one individual, namely the species Carangoides plagioenia of the family Carangidae, Category types and feeding habits of the fish in the area at the Beach breakwater buildings consist of 14 species of fish targets and 8 major fish species, while the eating habits of the fish listed nine types of herbivorous fish species, 11 types of carnivorous fish species, two species of omnivorous fish types. Fish ecology index showed an unstable community with dominance index which tends to be low and fish species are spread relatively evenly and Non-Breakwater showed that depressed communities with dominance index tend to be high and fish species are not evenly distributed.
\end{abstract}

Keywords: breakwater, new habitat, species composition

\section{PENDAHULUAN}

Pantai matras adalah salah satu objek wisata pantai yang terdapat di Bangka Belitung. Pantai yang terletak di Desa Sinar Baru, Kecamatan Sungailiat memiliki keindahan alami yaitu pasir yang putih dengan tekstur halus serta tergolong pantai yang landai. Pantai Matras memiliki panjang kurang lebih $3 \mathrm{~km}$ dengan lebar 20-30 meter. Pada bulan November sampai Maret Pantai Matras mengalami abrasi pantai dikarenakan letak Pantai Matras menghadap langsung ke arah Laut Cina Selatan serta peningkatan gelombang air laut setiap tahun, sehingga perlu dibangunnya bangunan pemecah gelombang atau breakwater (Tour, 2014).

Pemecah gelombang atau breakwater adalah prasarana yang dibangun untuk memecahkan ombak/gelombang, dengan cara menyerap sebagian energi yang dihasilkan oleh gelombang. Struktur ini memberikan perlindungan dengan mengurangi energi gelombang yang mencapai perairan dan pantai di belakangnya (Lubis, 2011). Salah satu fungsi ekologi bangunan breakwater adalah terciptanya habitat baru. Suhendro et al (2014) menyatakan bahwa salah satu keuntungan bangunan breakwater yang dibangun dengan tumpukan material batu-batuan besar akan terbentuk rongga yang dapat berfungsi sebagai habitat baru bagi biota laut untuk tempat bermain, mencari makan, berlindung serta berkembang biak. Menurut Lestari et al (2018) karakteristik bangunan pemecah gelombang pada Pantai Matras yaitu tipe bangunan pemecah gelombang lepas pantai dengan bentuk sisi miring.

Dugaan keterkaitan area bangunan breakwater di Pantai Matras sebagai tempat berlindung ikan yaitu banyak terbentuknya celah-celah dan rongga dari tumpukan batu yang masih terendam air laut dapat ditumbuhi alga dan terjadinya rekruitmen karang serta dihadiri spesies ikan pemakan alga dan ikan predator. Terbentuknya habitat baru serta terjadi kompetisi sumber makanan dan tempat berlindung antara sesama spesies maupun beda spesies yang masih memiliki keterkaitan dengan spesies ikan pada daerah sekitarnya. Spesies ikan yang tidak mampu mengkolonisasi habitat lama akan berpindah dengan cara bermigrasi ke lokasi baru dengan membentuk komunitas. Kajian tentang area banguan breakwater terhadap daerah berlindung spesies ikan belum pernah dilaporkan, khususnya breakwater di Pantai Matras. Penelitian ini bertujuan untuk mengkaji area bangunan breakwater terhadap daerah lindung spesies ikan dengan mengetahui komposisi jenis dan kelimpahan ikan berdasarkan kategori jenis serta kebiasaan makan ikan dan indeks ekologi ikan pada area bangunan breakwater di Pantai Matras, Kabupaten 
Bangka. Penelitian ini diharapkan bermanfaat sebagai informasi tentang kondisi habitat baru ikan terkait dengan adanya daerah lindung ikan pada area bangunan breakwater di Pantai Matras, Kabupaten Bangka.

\section{METODE PENELITIAN}

Penelitian dilaksanakan pada bulan April 2019. Lokasi penelitian yaitu pada area bangunan breakwater dan NonBreakwater di Pantai Matras Kabupaten Bangka. Peta lokasi dapat dilihat pada Gambar 1.

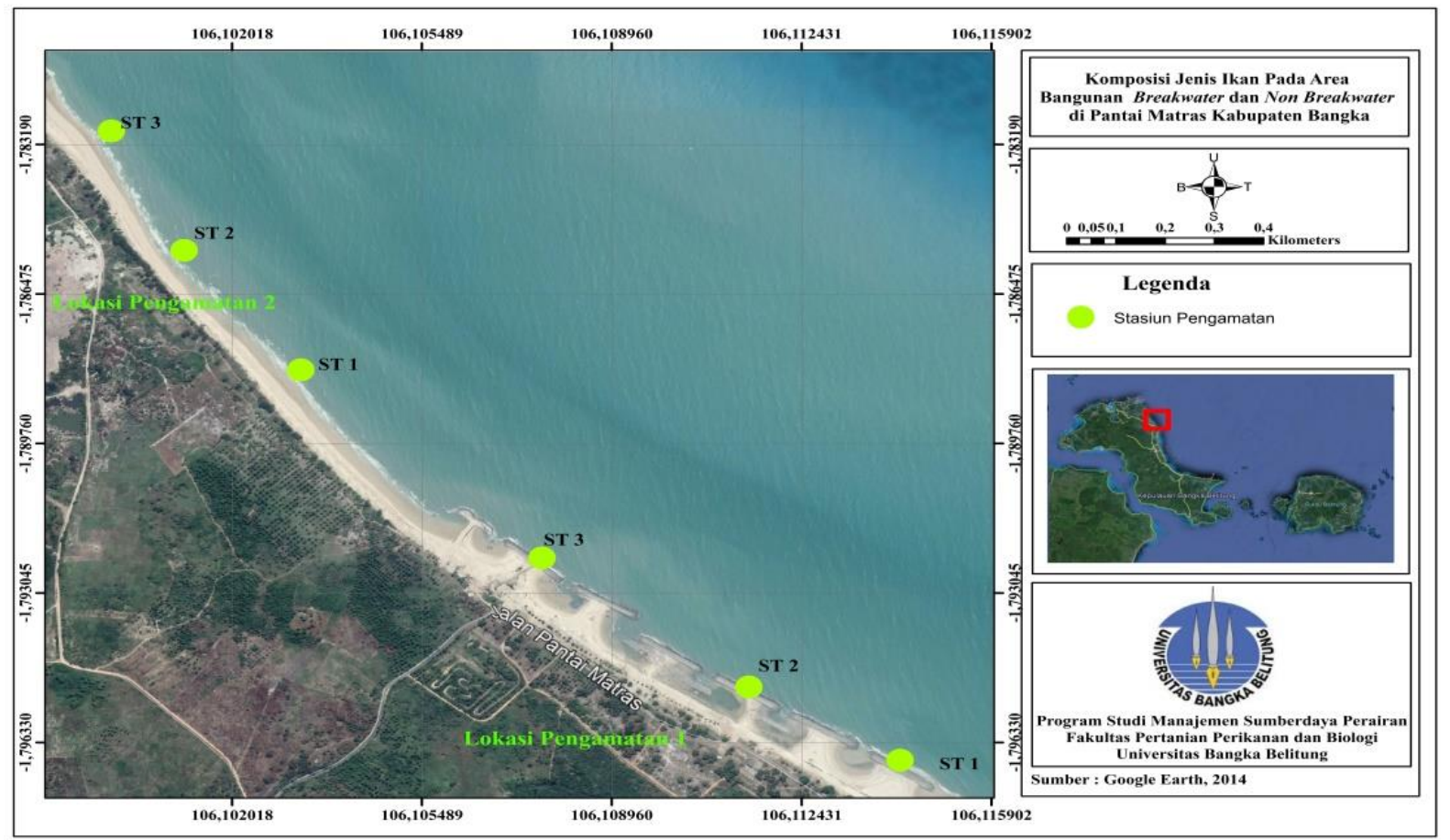

Gambar 1. Peta lokasi penelitian

Alat dan bahan yang digunakan dalam penelitian ini adalah jaring pantai sebagai alat untuk sampling, rollmeter sebagai alat pengukur panjang habitat ikan pada bangunan breakwater, alat selam atau SCUBA Set sebagai alat bantu pengambilan data, termometer sebagai alat pengukur suhu, refraktometer sebagai alat pengukur salinitas, sechi disk sebagai alat pengukur kecerahan perairan dan alat tulis bawah air (sabak) sebagai alat pencatatan data ikan serta buku identifikasi ikan berpedoman pada Reef Fish Identification Allen et al (2003) dan Panduan Lapangan Identifikasi Ikan Karang dan Invertebrate Laut Setiawan (2010).
Penentuan titik stasiun pengamatan penelitian dilakukan dengan metode Purposive Sampling. Metode ini merupakan teknik pengambilam sampel yang digunakan berdasarkan pertimbangan tertentu oleh peneliti (Fachrul, 2007). Stasiun pengambilan data yaitu sebanyak 2 lokasi dengan setiap lokasi memiliki 3 stasiun pengamatan. Lokasi pengamatan 1 terdapat pada area bangunan pemecah gelombang atau breakwater sedangkan lokasi pengamatan 2 terletak pada area pantai dengan jarak $500 \mathrm{~m}$ dari bangunan breakwater di Pantai Matras Kabupaten Bangka. Pembagian stasiun pada kedua lokasi pengamatan dapat dilihat pada Tabel 1.

Tabel 1. Titik Lokasi Penelitian

\begin{tabular}{|c|c|c|c|c|}
\hline \multicolumn{2}{|c|}{ Lokasi Pengamatan } & \multicolumn{2}{|c|}{ Titik Koordinat } & \multirow{2}{*}{$\begin{array}{c}\text { Keterangan } \\
\text { Aktivitas wisatawan }\end{array}$} \\
\hline \multirow{4}{*}{ Breakwater } & ST I & $1^{\circ} 47^{\prime} 49.243 ’ \mathrm{LS}$ & $106^{\circ} 6^{\prime} 49.525 \mathrm{BT}$ & \\
\hline & ST II & $1^{\circ} 47^{\prime} 42.814^{\prime \prime} \mathrm{LS}$ & $106^{\circ} 6^{\prime} 40.230^{\prime \prime} \mathrm{BT}$ & Tidak ada aktivitas \\
\hline & ST III & $1^{\circ} 47^{\prime} 33.504^{\prime \prime L S}$ & $106^{\circ} 6 ’ 26.914$ 'BT & Parkir perahu nelayan \\
\hline & ST I & $1^{\circ} 47^{\prime} 19.280^{\prime \prime L S}$ & $106^{\circ} 6^{\prime} 12.103^{\prime \prime} \mathrm{BT}$ & Aktivitas wisatawan \\
\hline \multirow{2}{*}{ Pantai } & ST II & $1^{\circ} 47^{\prime} 9.679 ’ \mathrm{LS}$ & $106^{\circ} 63.805^{\prime \prime} \mathrm{BT}$ & Tidak ada aktivitas \\
\hline & ST III & $1^{\circ} 47^{\prime} 0.028^{\prime \prime} \mathrm{LS}$ & $106^{\circ} 6 ' 58.013^{\prime \prime} \mathrm{BT}$ & Bekas dermaga pasir \\
\hline
\end{tabular}

Pengambilan data komposisi jenis ikan menggunakan kombinasi jaring insang tetap dan metode visual sensus yang secara teknis dilakukan dengan metode transek dengan transek sabuk (Belt Transect) (Setiawan, 2010).

Pengambilan data ikan dilakukan dengan jaring insang atas dengan 4 mata jaring yang berbeda, ukuran $0,1,1$, 1,5 dan 2 inch, panjang $25 \mathrm{~m}$, lebar 1,5 m. Pemasangan jaring insang atas yaitu sejajar garis pantai atau menyesuaikan kondisi area pengamatan dengan memperhatikan sifat ikan yang beruaya. Pengambilan data ikan dilakukan selama 24 jam pada area bangunan breakwater dan perairan pantai di Pantai Matras Kabupaten Bangka. 
Pengamatan metode visual sensus dilakukan secara observasi mencatat secara langsung ikan yang dilihat (Setiawan, 2010). Peneliti akan mengamati ikan sepanjang bangunan breakwater dan melakukan pendataan jenis dan jumlah individu ikan, selanjutnya dilakukan juga dokumentasi terhadap jenis-jenis ikan yang ada di setiap lokasi, menggunakan underwater camera. Ikan diidentifikasi di Laboratorium Manajemen Sumberdaya Perairan Universitas Bangka Belitung dengan menggunakan buku identifikasi ikan berpedoman pada Reef Fish Identification Allen et al (2003) dan Panduan Lapangan Identifikasi Ikan Karang dan Invertebrate Laut Setiawan (2010).

Analisis data yang digunakan yaitu:

Data yang diperoleh seperti jumlah dan jenis spesies hasil pengamatan visual sensus dan hasil tangkapan jaring insang dianalisis kedalam tabel untuk mengetahui komposisi jenis serta mengetahui persentase kelimpahan spesies. Analisis kelimpahan relatif setiap jenis ikan dilakukan dengan perhitungan persentase jumlah. Untuk mengetahui Kelimpahan relatif ikan menggunakan formula:

Dimana:

$$
(\mathrm{Kr})=\frac{\mathrm{ni}}{N} \times 100 \%
$$

$\mathrm{Kr}=$ Kelimpahan Relatif

$\mathrm{N}=$ Jumlah total individu semua spesies

ni $=$ Jumlah individu spesies ke-i

Indeks keanekaragaman digunakan untuk mengukur kelimpahan komunitas berdasarkan jumlah jenis spesies dan jumlah individu dari setiap spesies di suatu lokasi. Semakin banyak jumlah jenis, maka semakin beragam komunitasnya. Indeks keanekaragaman ikan digunakan indeks ShannonWiener (Setyobudiandy et al, 2009):

$$
\mathrm{H}^{\prime}=-\sum_{\mathrm{i}=1}^{\mathrm{s}} \mathrm{pi} \ln \mathrm{pi}
$$

Dimana:

$\mathrm{H}^{\prime}=$ Indeks keanekaragaman Shannon-Wiener

$\mathrm{Pi}=$ Perbandingan antara jumlah individu ikan ke-i dengan jumlah seluruh jenis ikan

Indeks keseragaman digunakan untuk mengetahui seberapa besar kesamaan penyebaran jumlah individu setiap jenis yaitu dengan membandingkan indeks keanekaragaman dengan nilai maksimumnya. Indeks keseragaman ditentukan berdasarkan rumus (Setyobudiandi et al., 2009):

$$
\mathrm{E}=\frac{H^{v}}{\ln s}
$$

Dimana:

$\mathrm{E}=$ Indeks keseragaman

$\mathrm{H}^{\prime}=$ Indeks keanekaragaman

$\mathrm{S}=$ Jumlah total spesies

Indeks dominansi digunakan untuk menggambarkan jenis yang paling banyak ditemukan dapat diketahui dengan menghitung nilai dominansinya. Indeks dominansi dihitung dengan menggunakan rumus (Setyobudiandi et al., 2009):

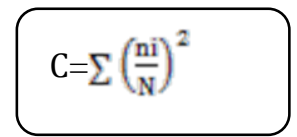

Dimana:

$\mathrm{C}=$ Indeks dominansi

$\mathrm{ni}=$ Jumlah individu jenis ke-i

$\mathrm{N}$ = Jumlah total individu seluruh jenis

Tabel 2. Kriteria nilai struktur komunitas

\begin{tabular}{lll}
\hline Indeks & Kisaran & Kategori \\
\hline Dominansi (C) & $0,00<\mathrm{C} \leq 0,50$ & Rendah \\
& $0,50<\mathrm{C} \leq 0,75$ & Sedang \\
& $0,75<\mathrm{C} \leq 1,00$ & Tinggi \\
\hline Keanekaragaman (H') & $\mathrm{H}^{\prime} \leq 1$ & Rendah \\
& $1<\mathrm{H}^{\prime} \leq 3$ & Sedang \\
& $\mathrm{H}^{\prime} \geq 3,0$ & Tinggi \\
\hline Keseragaman (E) & $0,00<\mathrm{E} \leq 0,50$ & Komunitas dalam kondisi tertekan \\
& $0,50<\mathrm{E} \leq 0,75$ & Komunitas dalam kondisi labil \\
& $0,75<\mathrm{E} \leq 1,00$ & Komunitas dalam kondisi stabil \\
\hline
\end{tabular}

Sumber: (Setyobudiandy et al, 2009).

\section{HASIL DAN PEMBAHASAN}

\section{Gambaran Lokasi Penelitian dan parameter lingkungan}

Kondisi lokasi penelitian pada Pantai Matras terdiri dari dua karakteristik yang berbeda. Lokasi pertama yaitu sisi miring area bangunan Breakwater yang masih terendam air laut, sedangkan lokasi kedua yaitu perairan pantai. Secara visual kondisi lokasi penelitian pertama yaitu area tumpukan batu-batuan besar yang masih terendam air laut terbentuk celah-celah dan rongga serta banyak ditumbuhi alga dan karang (Gambar 2). Sedangkan pada lokasi kedua, dasaran perairan pantai dengan tekstur pasir halus. Menurut Choat dan Bellwood (1991) dalam Maharbakti (2009) karakteristik ekologi ekosistem terumbu karang tidak hanya terdiri dari karang saja, tetapi juga daerah berpasir, alga, goa dan lubang atau celah. 


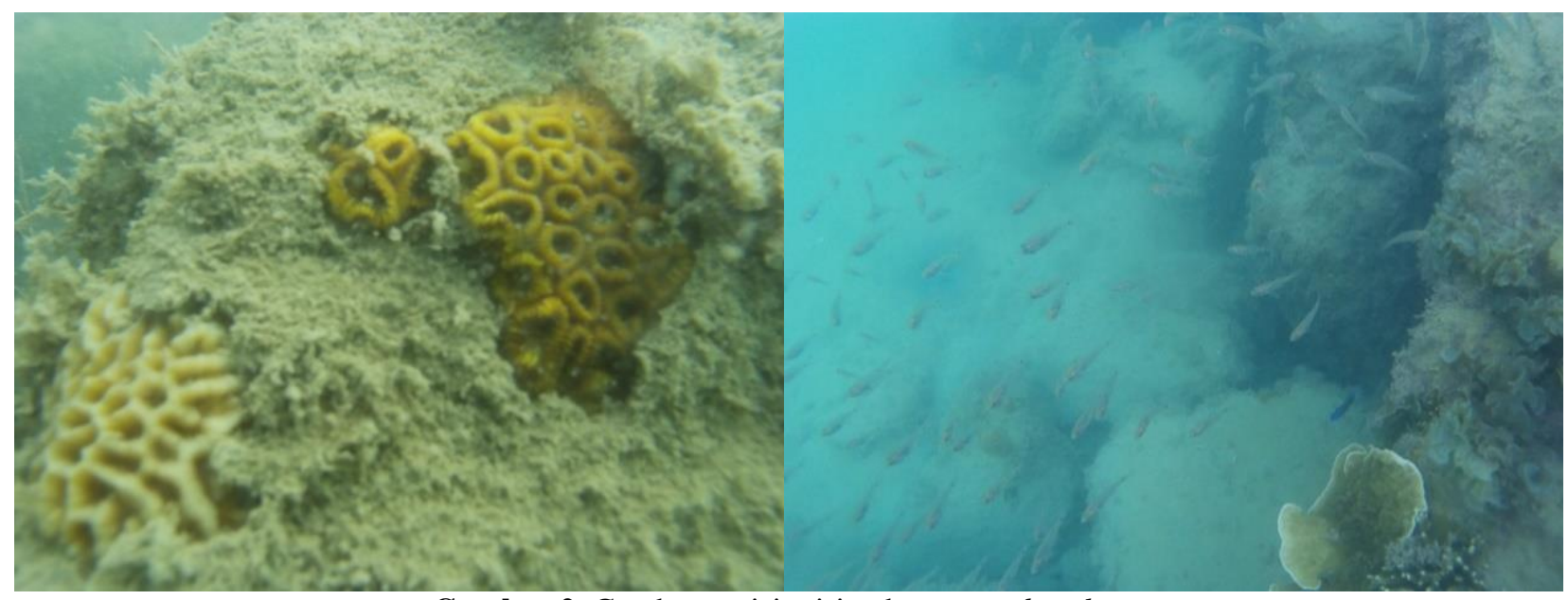

Gambar 2. Gambaran sisi miring bangunan breakwater

Kondisi lingkungan perairan pantai matras mengindikasikan bahwa suhu, salinitas, $\mathrm{pH}$, oksigen terlarut (DO), Total Suspended Solid (TSS) tidak melebihi baku mutu KepmenLH No. 51 Tahun 2004 untuk biota laut. Hasil pengukuran beberapa parameter lingkungan perairan pada stasiun pengamatan terdapat pada Tabel 3.

Tabel 3. Hasil pengukuran parameter lingkungan perairan Pantai Matras

\begin{tabular}{|c|c|c|c|c|c|c|}
\hline \multirow[b]{3}{*}{ Parameter Fisika-Kimia } & \multicolumn{3}{|c|}{ Lokasi I (Breakwater) } & \multicolumn{3}{|c|}{ Lokasi II (Non-Breakwater) } \\
\hline & \multicolumn{3}{|c|}{ Stasiun } & \multicolumn{3}{|c|}{ Stasiun } \\
\hline & I & II & III & I & II & III \\
\hline Suhu & 29 & 30 & 31 & 30 & 31 & 31 \\
\hline Salinitas & 31 & 30 & 31 & 30 & 31 & 30 \\
\hline Kecerahan & 2.75 & 3.05 & 2.525 & 2.475 & 2.475 & 2.45 \\
\hline $\mathrm{pH}$ & 7 & 7 & 7 & 7 & 7 & 7 \\
\hline DO & 7.65 & 7.62 & 7.29 & 7.23 & 6.78 & 7.05 \\
\hline TSS & 190 & 160 & 170 & 150 & 150 & 170 \\
\hline
\end{tabular}

Nilai suhu rata-rata perairan di setiap lokasi penelitian pada Pantai Matras yaitu $29-31^{\circ} \mathrm{C}$. Kisaran nilai suhu perairan di setiap lokasi penelitian pada Pantai Matras masih merupakan kisaran optimal bagi kehidupan ikan. Menurut Kordi dan Tancung (2007) bahwa kisaran suhu optimum bagi kehidupan ikan di perairan tropis adalah antara $28^{\circ}-32^{\circ} \mathrm{C}$. dimana suhu perairan mempengaruhi aktivitas metabolisme ikan dan sangat berkaitan dengan oksigen terlarut dan konsumsi oksigen oleh ikan.

Total Suspended Solid (TSS) di setiap lokasi penelitian pada Pantai Matras memiliki nilai rata-rata yaitu 173.333-156.667 mg/l. Nilai kecerahan perairan di setiap lokasi penelitian pada Pantai Matras memiliki rata-rata 2.45- 3.05 meter. Tebaiy, et al., (2014) mengindikasikan bahwa tingginya kelimpahan ikan disebabkan oleh tingginya nilai kecerahan. Kecerahan suatu perairan yang baik menandakan bahwa optimalnya intensitas cahaya matahari yang menembus ke perairan. Hal ini akan sangat berpengaruh terhadap biota laut khususnya ikan. Ikan akan mudah melakukan pergerakan pada kondisi perairan yang cerah untuk mencari makan. Kecerahan mendukung proses penetrasi sinar matahari sampai ke kolom perairan sehingga proses fotosintesis dapat berlangsung.

Tabel 4. Komposisi jenis dan kelimpahan ikan pada area bangunan breakwater
Pantai Matras memiliki nilai rata-rata 29-30 ppt. Hasil pengukuran $\mathrm{pH}$ perairan di setiap lokasi penelitian pada Pantai Matras memiliki nilai rata-rata 7. Hasil pengukuran salinitas dan $\mathrm{pH}$ perairan di setiap lokasi penelitian pada Pantai Matras masuk dalam baku mutu kualitas perairan laut untuk ikan. Hasil pengukuran oksigen terlarut (DO) dalam air di setiap stasiun penelitian pada area bangunan breakwater memiliki nilai rata-rata $7.52 \mathrm{mg} / \mathrm{l}$, sedangkan rata-rata di setiap non-breakwater memiliki nilai rata-rata 7.1. Hasil ini menunjukan bahwa lokasi penelitian pada area bangunan breakwater dan non-breakwater ini mencapai baku mutu peairan laut untuk biota ikan. Standar baku mutu air laut untuk biota ikan adalah $>5 \mathrm{mg} / \mathrm{l}$ (KepmenLH No. 51, 2004). Akhrianti (2014) menyatakan konsentrasi DO juga memiliki keterkaitan dengan kelimpahan ikan. Peranan DO cukup penting yakni untuk pernafasan dan juga merupakan salah satu komponen utama bagi metabolisme organisme perairan.

\section{Komposisi Jenis dan Kelimpahan Ikan}

Hasil komposisi jenis dan kelimpahan jenis ikan yang ditemukan pada area bangunan breakwater di Pantai Matras ditampilkan pada Tabel 4.

\begin{tabular}{lllll}
\hline No & Famili & Spesies & Jumlah & Kr (\%) \\
\hline
\end{tabular}




\begin{tabular}{cllcc}
\hline \multirow{2}{*}{1} & Apogonidae & Apogon fragilis & 287 & 7.672 \\
2 & Atherinidae & Hypogon hoexenii & 26 & 0.695 \\
3 & Bolonidae & Tylosorus crocodilus & 840 & 22.454 \\
4 & Carangidae & Selaroides leptolepis & 8 & 0.214 \\
5 & Holocentridae & Myripristis hexagona & 74 & 1.978 \\
6 & Labridaea & Halichoeres chloropterus & 12 & 0.321 \\
& & Equulites leuciscus & 13 & 0.348 \\
7 & Leiognathidae & Eubleekeria rapsoni & 47 & 1.256 \\
8 & Lethrinidae & Gnathodentex aureolineatus & 7 & 0.187 \\
& & Lutjanus ehrenbergii & 355 & 9.489 \\
9 & Lutjanidae & Lutjanus madras & 95 & 2.539 \\
& & Pentapodus trivittatus & 406 & 10.853 \\
10 & Nemipteridae & Scolopsis margaritifera & 33 & 0.882 \\
& & Pomacanthrus sextriatus & 16 & 0.428 \\
11 & Pomacanthidae & Abudefduf bengalensis & 2 & 0.053 \\
& & Cephalopholis boenak & 37 & 0.989 \\
12 & Serranidae & Gerres filamentosus & 1 & 0.027 \\
& & Siganus virgatus & 61 & 1.631 \\
13 & Siganidae & Siganus guttatus & 22 & 0.588 \\
& & Siganus javus & 839 & 22.427 \\
14 & Scorpaenidae & Scorpaenopsis oxycephala & 559 & 14.943 \\
\hline Total & 14 Famili & 22 Spesies & 1 & 0.027 \\
\hline
\end{tabular}

Hasil komposisi jenis ikan yang ditemukan pada area bangunan breakwater tercatat sebanyak 22 jenis ikan yang termasuk dalam 14 famili dengan jumlah individu 3741 ekor. Sedangkan jenis ikan yang ditemukan pada perairan Pantai Matras tercatat sebanyak 1 jenis ikan yang termasuk dalam family Carangidae yaitu ikan Carangoides plagiotaenia. Kelimpahan ikan pada area bangunan breakwater dominan dengan beberapa spesies tertinggi yaitu Hypoatherina barnesi sebesar 22.454\%, Siganus guttatus sebesar 22.427\%, Siganus javus (14.943\%), Lutjanus madras (10.853\%), Gnathodentex aureolineatus (9,489\%) dan Apogon fragilis (7,672\%) (Tabel 4). Struktur fisik bangunan breakwater dengan tumpukan batu-batuan yang besar terbentuk celah-celah dan rongga sangat cocok dijadikan habitat baru bagi ikan sebagai tempat berlindung dari predator, sehingga habitat ini merupakan daerah yang aman untuk ikan-ikan pada stadia juvenile tumbuh dewasa, hal ini telihat dengan ditemukan juvenile Siganus guttatus serta ikan lain yang berukuran kecil pada area bangunan breakwater di setiap stasiun pengamatan. Komposisi jenis dan kelimpahan ikan pada area bangunan breakwater masih menunjukan ada keterkaitannya dengan terumbu karang alami disekitarnya, dimana letak banguanan berada pada gugusan terumbu karang Batu Putih dan Turun Aban, sehingga ikan karang akan mudah menemukan area bangunan pemecah gelombang sebagai habitat baru. Menurut Ahmad dan Aunurohim (2015), rekrutmen kelompok ikan yang membentuk suatu komunitas pada suatu lokasi baru masih memiliki keterkaitan dengan komunitas ikan karang pada daerah sekitar dengan dipengaruhi variasi demografi lokalnya.

Banyaknya ikan kecil-kecil juga mengundang datangnya kelompok ikan predator pada area tersebut seperti ikan Lutjanide, Carangidae, Labridae dan Serranidae. Substrat batu-batuan yang masih terendam air laut dapat ditumbuhi alga dan karang, kepentingan dari spesies ikan karang datang (migrasi) ke area bangunan selain tempat untuk berlindung adalah untuk mencari makan. Hal ini terlihat secara visual banyak ditemukan spesies ikan dari famili Siganidae dan Pomacenthidae sebagai pemakan alga yang banyak tumbuh pada tumpukan batuan bangunan pemecah gelombang yang masih tergenang air laut. Manebu et al (2012) menyatakan bahwa sekitar 50-70\% ikan yang ada di terumbu karang merupakan ikan karnivora, 15-20\% kelompok herbivora sisanya omnivora.

Komposisi jenis ikan yang ditemukan pada area bangunan breakwater di Pantai Matras yaitu terdiri dari beberapa famili ikan karang dengan jumlah spesies yang berbeda seperti Apogonidae 2 jenis, Atherinidae 1 jenis, Bolonidae 1 jenis, Carangidae 2 jenis, Holocentridae 1 jenis, Labridae 2 jenis, Leiognathidae 2 jenis, Lethrinidae 1 jenis, Lutjanidae 2 jenis, Nemipteridae 2 jenis, Pomacanthidae 2 jenis, Serranidae 2 jenis, Siganidae 3 jenis. Setiawan (2010) mengemukakan ada beberapa jenis famili ikan karang yaitu famili Apogonidae, Atherinidae, Bolonidaes, Carangidae, Holocentridae, Labridae, Leiognathidae, Lethrinidae, Lutjanidae, Nemipteridae, Pomacanthidae, Serranidae dan Siganidae. 
Hasil komposisi jenis dan kelimpahan ikan berdasarkan kategori jenis dan kebiasaan makan ikan pada area bangunan breakwater ditampilkan pada Tabel 5.

Tabel 5. Komposisi jenis dan kelimpahan Ikan Berdasarkan Kategori Jenis dan Tipe Makan ikan pada area bangunan Breakwater

\begin{tabular}{|c|c|c|c|c|c|}
\hline No & Famili & Spesies & Kategori Jenis & Tipe Pemakan & Jumlah \\
\hline \multirow{2}{*}{1} & \multirow{2}{*}{ Apogonidae } & Apogon fragilis & Mayor & Herbivora & 287 \\
\hline & & Apogon hoexenii & Mayor & Herbivora & 26 \\
\hline 2 & Atherinidae & Hypoatherina barnesi & Mayor & Herbivora & 840 \\
\hline 3 & Bolonidae & Tylosorus crocodilus & Target & Karnivora & 8 \\
\hline 4 & Carangidae & selaroides leptolepis & Target & Karnivora & 74 \\
\hline 5 & Holocentridae & Myripristis hexagona & Mayor & Karnivora & 12 \\
\hline 6 & Labridaea & Halichoeres chloropterus & Mayor & Herbivora & 13 \\
\hline \multirow[t]{2}{*}{7} & \multirow{2}{*}{ Leiognathidae } & Equulites leuciscus & Target & Omnivora & 47 \\
\hline & & Eubleekeria rapsoni & Target & Omnivora & 7 \\
\hline 8 & Lethrinidae & Gnathodentex aureolineatus & Target & Karnivora & 355 \\
\hline \multirow[t]{2}{*}{9} & \multirow{2}{*}{ Lutjanidae } & Lutjanus ehrenbergii & Target & Karnivora & 95 \\
\hline & & Lutjanus madras & Target & Karnivora & 406 \\
\hline \multirow[t]{2}{*}{10} & \multirow{2}{*}{ Nemipteridae } & Pentapodus trivittatus & Target & Karnivora & 33 \\
\hline & & Scolopsis margaritifera & Target & Karnivora & 16 \\
\hline \multirow[t]{2}{*}{11} & \multirow{2}{*}{ Pomacanthidae } & Pomacanthrus sextriatus & Mayor & Herbivora & 2 \\
\hline & & Abudefduf bengalensis & Mayor & Herbivora & 37 \\
\hline \multirow[t]{2}{*}{12} & \multirow{3}{*}{ Serranidae } & Cephalopholis boenak & Target & Karnivora & 1 \\
\hline & & Gerres filamentosus & Target & Omnivora & 61 \\
\hline \multirow{3}{*}{13} & & Siganus virgatus & Target & Herbivora & 22 \\
\hline & \multirow[t]{2}{*}{ Siganidae } & Siganus guttatus & Target & Herbivora & 839 \\
\hline & & Siganus javus & Target & Herbivora & 559 \\
\hline 14 & Scorpaenidae & $\begin{array}{l}\text { Scorpaenopsis oxycephala } \\
\text { Jumlah Total }\end{array}$ & Mayor & Karnivora & $\begin{array}{c}1 \\
3741\end{array}$ \\
\hline
\end{tabular}

Sumber : Allen et al (2003) dan Setiawan (2010)

Hasil komposisi jenis ikan berdasarkan kategori jenis ikan pada area bangunan breakwater terdiri atas 14 jenis ikan target (ikan pangan) yang termasuk dalam 8 famili dan 8 jenis ikan mayor yang termasuk dalam 6 famili (Tabel 5), sedangkan ikan indikator tidak ditemukan. Berdasarkan kategori jenis ikan pada area bangunan breakwater di Pantai Matras, famili dan jenis ikan target lebih banyak ditemukan dibandingkan jenis ikan mayor. Menurut Panggabean (2012) jenis-jenis ikan tipe kelompok mayor yang mendiami suatu ekosistem terumbu karang memiliki ketergantungan hidup terhadap kondisi karang yang subur dan bahkan adakalanya memerlukan makanan yang spesifik terhadap jenis karang atau koral tertentu.

Hasil kelimpahan spesies ikan target tertinggi pada area bangunan breakwater yaitu dari famili Siganidae sebanyak 3 spesies dengan total individu sebanyak 1420 ekor, disusul dari famili Lutjanidae sebanyak 2 spesies dengan total individu 501 ekor, famili Lethrinidae sebanyak 1 spesies dengan total individu 355 ekor, famili Carangidae sebanyak 1 spesies dengan total individu 74 ekor, famili Serranidae sebanyak 2 spesies dengan total individu 62 ekor, famili Loignathidae sebanyak 2 spesies dengan total individu
54 ekor, famili Nemipteridae sebanyak 2 spesies dengan total individu 49 ekor, famili Bolonidae sebanyak 1 spesies dengan jumlah individu 8 ekor (Tabel 5). Menurut English et al (1997) ikan target adalah ikan konsumsi atau ikan pangan yang memiliki nilai ekonomis, sedangkan ikan mayor adalah kategori ikan meliputi semua yang tidak termasuk kedalam kategori target dan indikator. Lauwoie (2010) menambahkan kelompok ikan target yaitu ikan-ikan karang yang mempunyai manfaat sebagai ikan konsumsi, sedangkan ikan kelompok utama atau mayor yaitu ikan-ikan yang berperan dalam rantai makanan seperti ikan family Labridae dan Apogonidae.

Hasil kelimpahan spesies ikan mayor tertinggi pada area bangunan breakwater yaitu dari famili Athrinidae sebanyak 1 spesies dengan jumlah individu 840 ekor, disusul dari famili Apogonidae sebanyak 2 spesies dengan jumlah individu 313 ekor, famili Pomacanthidae sebanyak 2 spesies dengan jumlah individu 39 ekor, famili Lebridae sebanyak 1 spesies dengan jumlah individu 15 ekor, famili Holocentridae sebanyak 1 spesies dengan jumlah individu 12 ekor, famili Scorpaenidae sebanyak 1 spesies dengan jumlah individu 1 ekor (Tabel 5). Penggabean (2012), 
menyatakan besarnya kelimpahan jenis ikan kategori mayor (mayor family) dikarenakan adanya variasi habitat seperti berbatu, pasir, karang dan campuran batu pasir yang cocok bagi tempat hidup jenis-jenis ikan tertentu. Sehingga jenis ikan yang berkelompok tidak akan bermigrasi ketempat yang lebih jauh dikarenakan habitatnya sudah sesuai untuk perkembangan dan pertumbuhannya.

Makanan merupakan salah satu faktor penting bagi keberlangsungan hidup ikan (Muliati et al, 2017). Menurut Froese dan Pauly (2008), ikan terumbu berdasarkan makanannya atau pola pemangsaaan, dapat diklasifikasikan sebagai ikan terumbu pemakan segala (omnivora), pemakan hewan (karnivora) dan tumbuhan (herbivora). Hasil komposisi jenis ikan berdasarkan kebiasaan makan ikan pada area bangunan breakwater di Pantai Matras tercatat 9 spesies dari 6 famili tipe ikan pemakan herbivora, 10 spesies dari 8 famili tipe ikan pemakan karnivora, 3 spesies dari 2 famili tipe ikan pemakan omnivore (Tabel 5). Kehadiran ikan herbivora pada area bangunan breakwater merupakan adanya simbiosis ikan-ikan herbivora pemakan biota-biota sessile termasuk alga. Hal ini dapat dilihat dari kelimpahan ikan herbivora pada area bangunan breakwater di Pantai Matras yang membantu pertumbuhan karang dengan memakannya sehingga persaingan antara karang dan alga berkurang. Menurut Utami (2010) berlimpahnya alga menandakan suatu perairan tersebut sedang mengalami pemulihan dengan adanya biota yang menempel di terumbu karang buatan seperti alga sebagai daya tarik ikan herbivora.

\section{Indeks Ekologi Ikan}

Hasil analisis inseks ekologi ikan yaitu indeks keanekaragaman (H'), keseragaman (E) dan dominansi (C) pada area bangunan Breakwater di Pantai Matras ditampilkan dalam Tabel 6.

Tabel 6. Nilai indeks keanekaragaman (H'), keseragaman (E) dan dominansi (C)

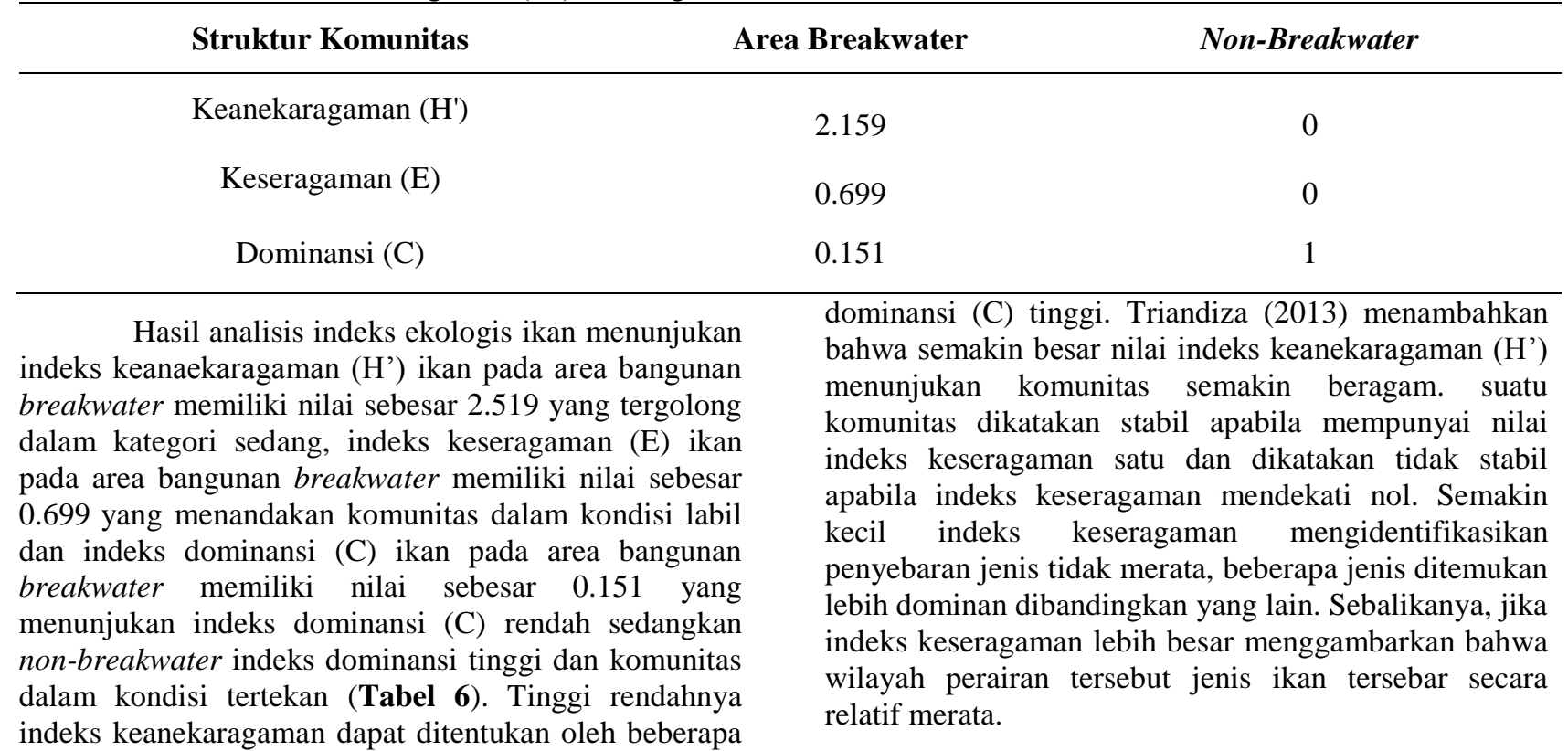
faktor antara lain jumlah jenis yang ditemukan, kondisi ekosistem perairan sebagai habitat dan adanya jenis yang melimpah dibandingkan jenis yang lainnya. Hasil penelitian tercatat jumlah spesies ikan yang ditemukan pada area bangunan breakwater sebanyak 22 spesies dari 14 famili dan beberapa spesies ditemukan dalam kelompok dengan jumlah besar seperti spesies Hypoatherina barnesi, Siganus guttatus, Siganus javus, Lutjanus madras, Gnathodentex aureolineatus dan Apogon fragilis. Kreteria indeks keanekaragaman ( $\left.\mathrm{H}^{\prime}\right)$, indeks keseragaman (E), dan dominansi (C) menurut Setyobudiandi et al (2009), nilai $\mathrm{H}^{\prime} \leq 1$, kreteria indeks keanekaragaman $\left(\mathrm{H}^{\prime}\right)$ rendah, nilai $1 \geq \mathrm{H}^{\prime} \leq 3$ kreteria indeks keanekaragaman ( $\left.\mathrm{H}^{\prime}\right)$ sedang, nilai $\mathrm{H}^{\prime} \geq 3$ kreteria indeks keanekaragaman ( $\mathrm{H}^{\prime}$ ) tinggi. nilai $0,00<\mathrm{E} \leq$ 0,50 , kreteria komunitas dalam kondisi tertekan, nilai $0,50<\mathrm{E} \leq 0,75$, kreteria komunitas dalam kondisi labil dan nilai $0,75<\mathrm{E} \leq 1,00$, kreteria komunitas dalam kondisi stabil. Sedangkan indeks dominansi (C), nilai $0,00<\mathrm{C} \leq 0,50$, kreteria indeks dominansi (C) rendah, nilai $0,50<\mathrm{C} \leq 0,75$, kreteria indeks dominansi (C) sedang dan nilai $0,75<\mathrm{C} \leq 1,00$, kreteria indeks

\section{KESIMPULAN DAN SARAN}

\section{Kesimpulan}

Kondisi area bangunan breakwater Pantai Matras memiliki karakteristik yaitu area sisi miring tumpukan batu-batuan besar yang masih terendam air laut terbentuk celah-celah dan rongga serta banyak ditumbuhi alga dan karang yang dimanfaatkan spesies ikan untuk berlindung dan mencari makan. Komposisi jenis dan kelimpahan ikan yang ditemukan pada area bangunan breakwater di Pantai Matras tercatat 22 spesies dari 14 famili dengan jumlah 3741 ekor yang masuk dalam 14 jenis ikan target yang termasuk dalam 8 famili, 8 jenis ikan mayor yang termasuk dalam 6 famili. Komposisi jenis ikan berdasarkan jenis makanan tergolong kedalam 3 jenis tipe makanan yaitu 9 spesies dari 6 famili tipe ikan herbivora 10 spesies dari 8 famili tipe ikan karnivora, 3 spesies dari 2 famili tipe ikan omnivora. Struktur komunitas ikan pada area bangunan breakwater di Pantai Matras menunjukkan komunitas yang labil dengan indeks dominansi yang cenderung 
rendah dan jenis ikan tersebar relatif merata, sedangkan pada area non-breakwater menunjukan komunitas yang tertekan dengan indeks dominansi cenderung tinggi dan jenis ikan tidak tersebar merata.

\section{Saran}

Untuk melengkapi informasi tentang komposisi jenis ikan pada area bangunan breakwater di Pantai Matras maka diperlukan penelitian lanjutan agar dalam pengelolaan sumberdaya perikanan berjalan lebih baik khususnya pada area bangunan breakwater di Pantai Matras.

\section{DAFTAR PUSTAKA}

Allen, G.R, Steene, R and Humann, P. 2003. Reef Fish Identification : Tropical Pacific. Florida.

Akhrianti, I. 2014. Distribusi Spasial dan Preferensi Habitat Bivalvia di Pesisir Kecamatan Simpang Pesak Kabupaten Belitung Timur. [Tesis]. Institut Pertanian Bogor. Bogor.

Choat, J.H and Bellwood, D.R. 1991. Reef Fishes : Their History and Evolutian. Ekologi of Fishes on Coral Reefs. Academic Press. San Diego.

English, S.C. Wilkinson, and V. Barker.1997. Survey Manual for Tropical Marine Resources. ASEANAustralian Marine Project. Australia.

Fachrul, M. F. 2007. Metode Sampling Bioekologi. Bumi Aksara. Jakarta.

Froese, R and Pauly, D. 2000. FishBase 2000 : Concepts, Design and Data Sources. ICLARM, Los Bafios, Laguna, Fhilippines. 344 p.

Keputusan Menteri Lingkungan Hidup No. 51 Tahun 2004. Tentang Baku Mutu Air Laut Untuk Biota. Kementrian Negara Lingkungan Hidup Republik Indonesia.

Kordi, M. G. H dan A. Tancung. 2007. Pengelolaan Kualitas Air Dalam Budidaya Perairan. Rineka Cipta. Jakarta.

Lauwoie, I. 2010. Keterkaitan Kondisi Terumbu Karang Dengan Kelimpahan Ikan Herbivora di Pesisir Selatan Teluk Kupang, Provinsi Nusa Tenggara Timur. [Tesis]. Institut Pertanian Bogor. Bogor.

Lestari, I. Hasyam, E. S. dan Gunawan, I. 2018. Analisis Efisiensi Pemecah Gelombang Kondisi Eksisting Dibandingkan Dengan Material Batu Bulat Halus. Prosiding Seminar Nasional Penelitian dan Pengabdian Masyarakat. Universitas Bangka Belitung. ISBN : 978-602-61545-0-7.

Lubis, S. M. 2011. Manajemen Pesisir. Institut Teknologi Bandung. Bandung. $42 \mathrm{p}$.

Maharbhakti, H.R. 2009. Hubungan Kondisi Terumbu Karang Dengan Keberadaan Ikan Chaetodontidae di Perairan Pulau Abang, Batam. [Tesis]. Institut Pertanian Bogor. Bogor.

Manembu, I., Adrianto, L., Bangen, D.G., dan Yulianda, F. 2012. Distribusi Karang dan Ikan Karang di Kawasan Reef Ball Teluk Buyat Kabupaten Minahasa Tenggara. Jurnal Perikanan dan Kelautan Tropis. 8 (1).

Muliati, Yasidi, F. dan Arami, H. 2017. Studi Kebiasaan Makan Ikan Baronang (Siganus canaliculatus) di Perairaan Tondonggeu Kecamatan Abeli Sulawesi Utara. Jurnal Manajemen Sumber Daya
Perairan. 2 (4) : 287-294.

Panggabean, A.S. 2012. Keanekaragaman Jenis Ikan Karang dan Kondisi Kesahatan Karang di Pulau Gof dan Yep Nabi Kepulauan Raja Ampat. J. Lit. Perikanan. Ind. 18 (2) : 109-115.

Setiawan, F. 2010. Panduan Lapangan Identifikasi Ikan Karang dan Invertebrata Laut. Institut Pertanian Bogor. Bogor.

Setyobudiandi, I., Sulistiono., F. Yulianda., C. Kusmana, C.,S. Hariyadi.,A. Damar., A.Sembiring dan Bahtiar. 2009. Sampling dan Analisis Data Perikanan dan Kelautan; Terapan Metode Pengambilan Contoh di Wilayah Pesisir dan Laut. Fakultas Perikanan dan Ilmu Kelautan. Institut Pertanian Bogor. Bogor. 312 pp.

Suhendro, B. Yuwono, N. Darsono, S. 2014. Transmisi dan Refleksi Gelombang Pada Pemecah Gelombang Ambang Rendah Ganda Tumpukan Batu. Jurnal MKTS. 20 (2):179-187.

Tebaiy, S., Fredinan Yulianda, Achmad Fahrudin, dan Ismudi Muchsin. 2014. Struktur Komunitas Ikan Pada Habitat Lamun Di Teluk Youtefa Jayapura Papua. Jurnal Ikhtiologi Indonesia. 14 (1):49-65.

Tour, C.B. 2014. Pantai Matras Sungailiat Bangka. https://www.cakrabuanatour.com/2014/04/objekwisata-pantai-matras-bangka.html.

$[11$ November 2019].

Triandiza, T. 2013. Diversitas Ikan Pada Komunitas Padang Lamun Di Pesisir Perairan Pulau Kei Besar, Maluku Tenggara. Seminar Nasional Sains \& Teknologi V: Lampung: Lembaga Penelitian Universitas Lampung 19-20 November 2013. Lampung: UPT Loka Konservasi Biota Laut Tual-LIPI Universitas Lampung. hlm 666677.

Utami, T.S. 2010. Suksesi Komunitas Ikan Karang Pada Lokasi Rehabilitasi Terumbu Karang Di Pulau Kelapa, Kepulauan Seribu. [Skripsi]. Institut Pertanian Bogor. Bogor.

Yanuar, A dan Aunurohim. 2015. Komunitas Ikan Karang Pada Tiga Model Terumbu Karang Buatan (Artificial Reef) di Perairan Pasir Putih Situbondo. Jurnal Sains dan ITS. 4 (1) :23373520 . 